\title{
ANALYSIS OF THE PROFITABILITY OF THE RESTITUTION OF FIRE-AFFECTED BEECH FORESTS IN SERBIA
}

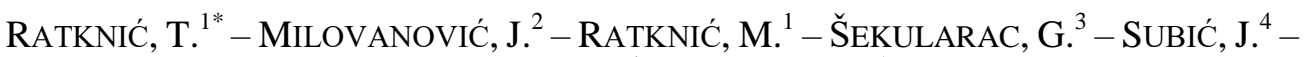 \\ JELOČNIK, M. ${ }^{4}-$ PODUŠKA, Z. ${ }^{1}$ \\ ${ }^{1}$ Institute of Forestry, Kneza Višeslava 3, Belgrade, Serbia \\ ${ }^{2}$ Faculty of Applied Ecology „,Futura”, Požeška Street 83a, 11030 Belgrade, Serbia \\ ${ }^{3}$ University of Kragujevac, Faculty of Agronomy, Cara Dušana 34, 32000 Čačak, Serbia \\ ${ }^{4}$ Institute of Agricultural Economics, Volgina st. 15, p.o.b. 93, 11030 Belgrade, Serbia \\ *Corresponding author \\ e-mail: tatjanaratknic@yahoo.com \\ (Received $3^{\text {rd }}$ Jul 2017; accepted $26^{\text {th }}$ Oct 2017)
}

\begin{abstract}
The number of forest fires in Serbia caused by climate change has been continuously growing in recent decades, thus making the rehabilitation of the burned area increasingly important. In the period from 2003 to 2015, the total burned area (42.2\%) was in beech forests. Cost-Benefit Analysis (the dynamic and the static approaches) was used as an approach to estimating the effects that restitution of beech forests can have on the environment, with the aim of finding the best solutions and making the best decisions about the desirability of the project. The dynamic approach (the analysis of tangible benefits and costs) led us to the conclusion that the investment in the restitution of beech forests destroyed by fires could be profitable only if it was based on wood production. Wood production may, depending on the site class, bear slightly higher interest rates (to better site classes) compared to previous estimates which ranged mainly around 3\%. At lower discount rates (on poor quality sites), it takes more time to reach the break-even point, while the period of time needed to reach the break-even point shortens with higher discount rates. According to the static approach (the analysis of intangible benefits and costs) the benefits outweigh the costs, which makes the restitution of beech forests destroyed by fires acceptable.
\end{abstract}

Keywords: forest fire, beech forests, restitution, financial analysis, economic analysis

\section{Introduction}

Forests have always been considered as national treasures of a country. In addition to their ecological role in the preservation of important life cycles, they have other relevant economic and social (tourism, recreation, health) functions. Most of forest functions and their ecosystem services are not fully "captured" in comercial market (Costanza et al., 1997). This situation produce lack of valuation of ecoystem services what directy influence in sustainability of humans in the biosphere. There are many reasons for quoetionable in sustainability but one of most citet tiday can be found in processes of climate change. Forests are particularly vulnerable to climate change because they are not easily adapted to new environmental conditions.

The effects of modern civilization on climate change are becoming increasingly apparent. There has been an obvious trend of global temperature rise of $0.8^{\circ} \mathrm{C}$ since 1900 (Hansen et al., 2010). According to the European climate change scenario for 2100 , the temperature is likely to rise by $2.8^{\circ} \mathrm{C}$ in Ireland and the $\mathrm{UK}$, by $3.8^{\circ} \mathrm{C}$ in Central Europe and $4-5^{\circ} \mathrm{C}$ in Southern Europe (Christensen et al., 2007). 
The number of forest fires caused by climate change has been continuously growing in recent decades, thus making the rehabilitation of the burned area increasingly important. This number ranges between 50,000 and 70,000 fires a year in Europe. They affect 3,000 to $5,000 \mathrm{~km}^{2}$ and cause millions of euro worth damage. Forest fires cause significant environmental, economic and social issues in many European countries, with possible long-term effects on the natural environment and the economy.

Climate change increases the risk of forest fire occurrence and spread (Allen et al., 2010; Ertuğrul and Varol, 2016). There are a large number of models and official reports that predict that the risk of forest fires will be increasing in the future (Flannigan et al., 2009; Aleksić et al., 2009; Sekulić et al., 2012). The climate, with the doubled amount of carbon dioxide in nature, will extend the fire season and increase the frequency and intensity of forest fires (Lindler et al., 2010). These predictions are so serious that they call for urgent changes in the forest fire management and the establishment of modern fire protection organization.

The total area of forests in Serbia amounts to 2,252,400 ha, or $29.1 \%$ of its territory (Banković et al., 2009). The state-owned forests account for $53.0 \%$ and privately-owned for $47.0 \%$ of the forested area. High intensity and frequency of fires may affect the sustainable management of forests to a certain extent. There is a general concern that the territory of Serbia has been affected by an increasing number of forest fires and this trend can cause substantial losses to forestry. Serbia has already recorded an increase in the frequency, intensity and duration of droughts. This trend will in the near future be particularly expressed in the southeast and east of Serbia.

The vulnerability of forest ecosystems depends on the ability of natural ecosystems to resist adverse influences (Schröter et al., 2005). Forest fires affect the forest ecosystem, and often seriously hinder its functioning over a longer period before it is restored to the state before the fire (González-Cabán, 2013). Proces of revitalization forest ecosistems is a matter of making the right choises, espoecialy from the aspect of income effect (Broberg, 2007).

Since revitalization of forest ecosystems requires significant financial funds, these sites are often left to natural regeneration. On the other hand, it is questionable whether the investment into the establishment of forest stands with the species that used to grow at these locations is reasonable at all.

In Serbia, in the period from 2003 to 2015, the total burned area (42.2\%) was in beech forests. In this situation, the restitution of these forests after they have been damaged by forest fires is of huge economic importance. The process of forest restitution raises the issue of financing and assessing the profitability of the investment.

This problem can be viewed from many different aspects, but the main questions to be answered are:

- What will be produced and how much of it, i.e. which products will carry the greatest burden of repaying the financial liabilities?

- What discount rates should be applied in the assessment of profitability?

The main goal was to make an economic and financial analysis in order to examine the feasibility of the restitution of beech coppice forests, with the maximum considersation of ecological site characteristics.

It should be noted there has been no research related to the evaluation of the economic effeciency of investments in the artificial restitution of fire-damaged forest complexes (i.e. in the establishment of plantation). Previous analyses were mainly focused on the 
assessment of the cost-effectiveness of the establishment and exploitation of commercial plantations (artificially-established forest plantations) of certain genera of deciduous trees or on the evaluation of the investments in forest fire prevention.

For instance, Keča et al. (2009) applied some of the basic methods of dynamic assessment of the economic effeciency of investments (simple rates of yields, payback period, internal rate of return, net present value of the investment and cost-revenue ratio) in order to evaluate the investment in the establishment of an artificiallyestablished plantation of one of the poplar clones in Serbia, with the subsequent commercialization of wood mass (tree cutting) 29 years after the establishment. They concluded that in the current financing conditions (at a fairly high cost of borrowing in the financial market) such an investment would not be commercially viable for any of the applied parameters. The same authors came to a similar conclusion in the case of the establishment of a commercial poplar plantation with a 25 -year rotation period, with the recommendation that profitability would be achieved by lowering the capital costs to below $10 \%$, i.e. by reducing the rotation period to 20 years (Keča et al., 2008). Similar results, for high interest rate conditions, were obtained in the economic assessment of the plantation establishment in Latvia (Greğe-Staltmane and Tuherm, 2010).

On the other hand, the evaluations of the economic effeciency of investments in forest fire prevention measures, regardless of the method used, showed a certain level of economic viability (Mokhtari et al., 2017). Moreover, recent years have seen the development of risk assessment models and economic assessment of the management of forest fire risk which are of particular interest in the regions that are highly endangered by forest fires (Rodriguez y Silva and Gonzalez Caba, 2010; Gould et al., 2013; Calkin et al., 2014).

\section{Materials and Methods}

Given that the investment goal should be the highest possible level of the obtained economic effects per unit of the invested financial funds, the level of the effects depends on the quantity and quality of both the expenditures and the revenues. The economic effeciency of the investment is calculated as the ratio of the obtained effects to the realized investments, or as a ratio of the realized investments to the obtained effects (Cicea et al., 2008), according to the equation (1):

$$
e=\frac{E}{\varepsilon} \rightarrow \text { maximum or } e^{\prime}=\frac{\varepsilon}{E} \rightarrow \text { minimum }
$$

where $e$ and $e^{\prime}$ represent economic effeciency; $E$ is the obtained effect (the achieved result), while $\varepsilon$ represents the realized investment (spent resources).

In the first case, the formula expresses the economic effect that is obtained per unit of the realized investment and it should have the maximum value. In the second case, the formula presents the investments realized per unit of the obtained economic effects and it should be minimum.

Cost-Benefit Analysis (with the Dynamic and the Static Approaches) was used to assess the economic effeciency of the realized investments. The value of production was calculated without taking into account exploitation costs because they would quite complicate the analysis (over longer periods of time they can significantly change with the changes in technology). Besides, there is a trend to separate forest exploitation from silviculture. The value of wood was calculated using the stumpage price list of the 
Public Enterprise "Srbijašume" (2012). Another reason for excluding the exploitation costs is the fact that the money invested in the exploitation cannot greatly change the amount and profitability of the invested funds because it remains tied up in the production for a relatively short time (Pudar, 1985).

The analysis included the following costs: coating stumps to prevent regrowth (purchase costs - 40,000 RSD per hectare) and cutting the shoots in the third year after the restitution had been conducted and the new stands established (22,400 RSD per hectare).

The subsidy granted by the state was treated as profit (for the organizations that perform the restitution). It amounted to 150,000 RSD per hectare and covered the costs of soil preparation, the value of seedlings, planting costs, the costs of ploughing and weeding with the aim of establishing high forests.

The cost of buying forest land was not taken into account since the restitution of beech forests was planned to be carried out on the areas with well-defined ownership status.

The profit was analyzed through the value of wood assortments at certain ages. The data on wood yield and the relevant prices of wood assortments were used to make tables showing the value of wood of the studied tree species growing on the sites of different quality classes. The obtained values were discounted at the discount rate ranging from 2 to $10 \%$, which produced several different "current values", depending on the applied discount rate. The value of wood production was calculated for different lengths of the production cycle (from 20 to 140 years). All the calculated values are expressed per unit area (1 ha).

The value of wood assortments that were taken into account when calculating the value of the wood production was determined using the stumpage prices of sawlogs class I (5,783 RSD) sawlogs class II (4,728 RSD) sawlogs class III (3,917 RSD) mine timber $(4,852$ RSD), cordwood (3,595 RSD), pulpwood (2,655 RSD) and forest residue (2,175 RSD) ${ }^{1}$.

Apart from the tangible costs and benefits, the Cost-Benefit Analysis included a separate presentation of the intangible costs and benefits. Unlike the first approach (the dynamic approach), the second one (the static approach) was focused on the impact of beech forests on biodiversity (including species, ecosystem and genetic diversity), on environment, on the community and on the economy. For this reason, the dynamic method of assessing the profitability of the investments (net present value ${ }^{2}$ and internal rate of return ${ }^{3}$ ) was supplemented with the static method of determining the intangible costs and benefits (i.e. the ordinal scale of Cost-Benefit Analysis and the quantitative data processing were used).

\section{Results and Discussion}

\section{Tangible benefits and costs}

We analyzed the value of wood production for the observed tree species on sites of different quality classes (I to V), with different lengths of the production cycle (20-140 years) and at discount rates of 2, 3, 4, 5, 6, 8 and 10\%, since it was found that wood

\footnotetext{
${ }^{1} 1 \mathrm{EURO}=124.00 \mathrm{RSD}$

${ }^{2}$ Net present value represents the difference between the cash flows expected to be generated from the investment and the cash outflows needed for its acquisition and use in the initial stage of using the investment (moment $n=0)($ Subić, 2010). An investment is considered to be economically justified if its net present value is not negative (NPV>0), i.e. if the ratio between the inflows and outflows discounted at the initial moment of its use $(n=0)$ is greater than 0 .

${ }^{3}$ The internal rate of return can be defined as the interest rate, where the amount of monetary income from investments discounted at a given calculation moment is equal to the outflow needed for the purchase and use of the investment, discounted at the same calculation moment (Subić, 2010). The investment is economically viable when the internal rate of return is greater (or at least equal) than the assumed calculative interest rate (discount rate) (ISR $\geq \mathrm{i}$ ).
} 
production in forest cultures can be cost-effective only at discount rates lower than $10 \%$ (Brumelle et al., 1991).

In order to get a better insight into the flow of the current value of wood and the costs over time, we constructed graphs (Figs. 1, 2, 3) which show the curves of change in the current value of the wood of the given species at different site classes, depending on the length of the production cycle, for the six discount rates. The analysis of the data for all site classes shows that the investment in some site classes can be profitable even at slightly higher discount rates provided that the production cycle is short.

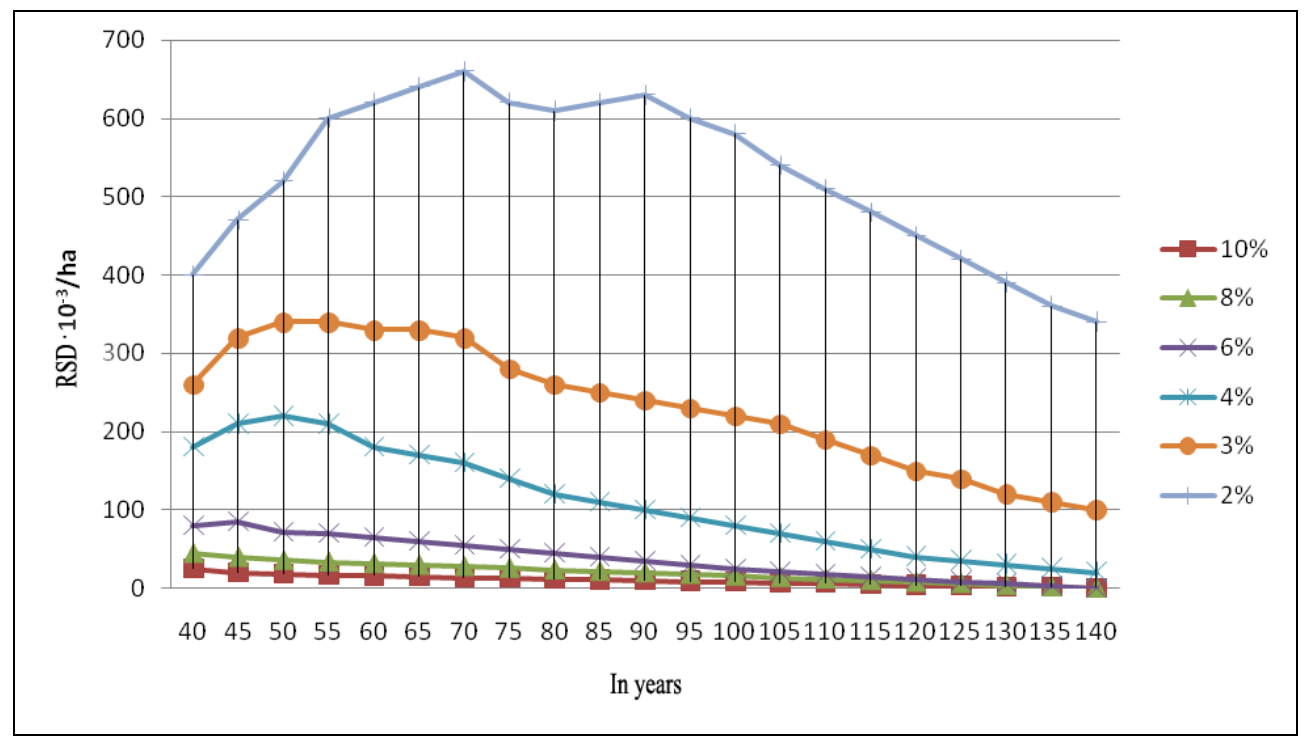

Figure 1. Changes in the current value of wood with the age at different discount rates (Beech Site class I).

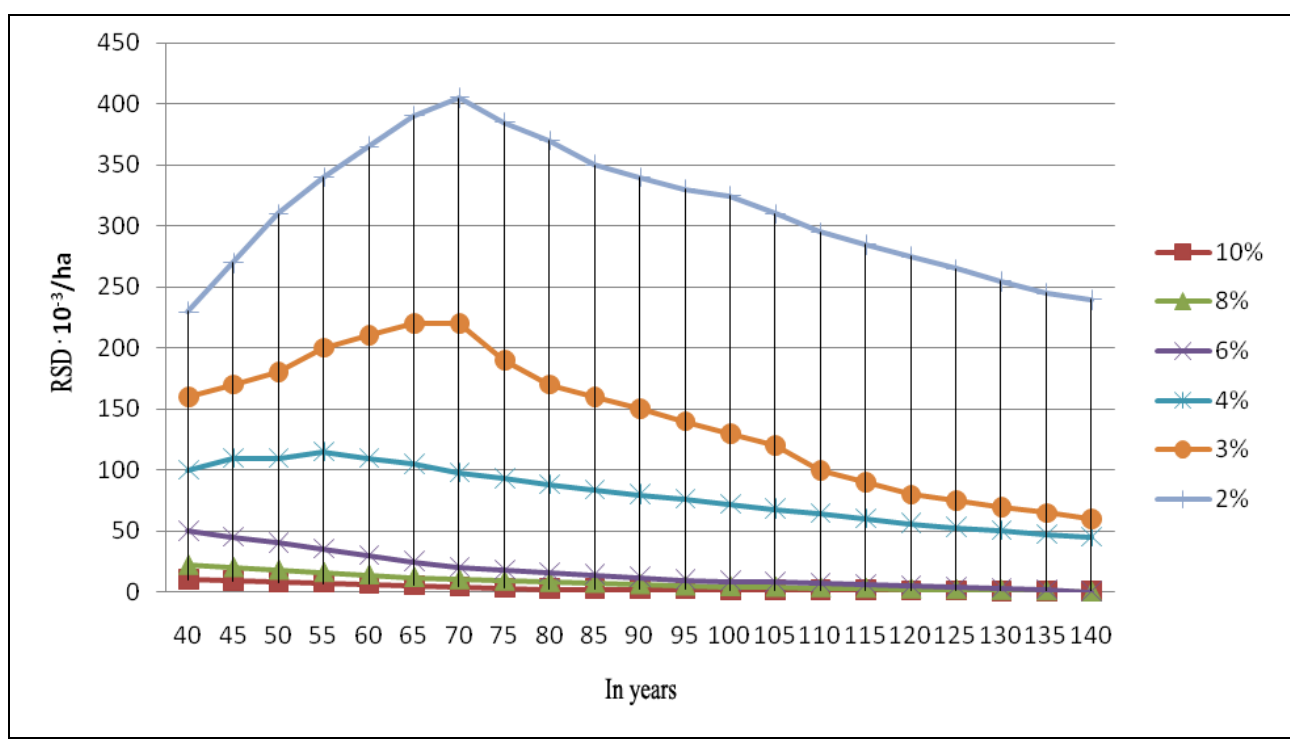

Figure 2. Changes in the current value of wood with the age at different discount rates (Beech Site class III). 


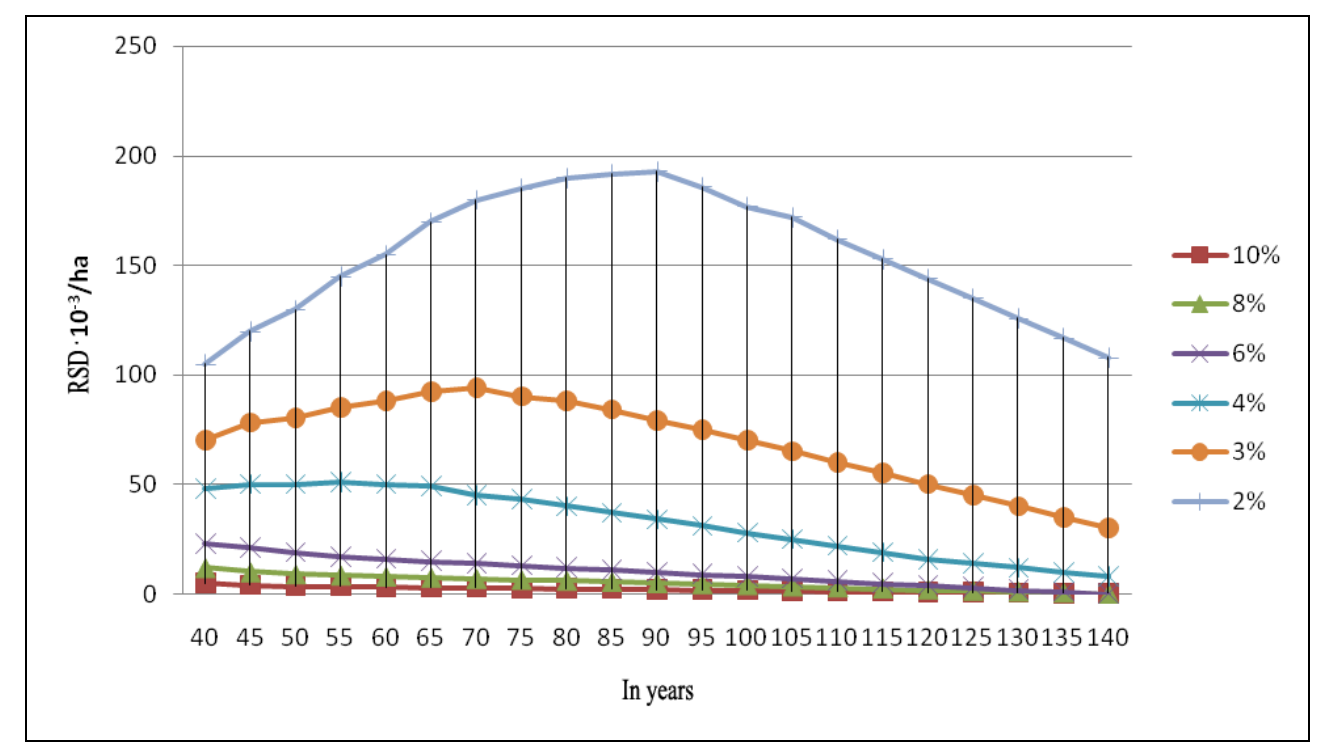

Figure 3. Changes in the current value of wood with the age at different discount rates (Beech Site class V).

Having in mind the equality of benefits and costs, we determined the highest discount rate and the maximum length of the production cycle at which the project could be expected to break even (Table 1). The table clearly shows that the discount rates at which the investment profitability is achieved are pretty lower than usual for similar projects (e.g. in agriculture). This indicates that wood production cannot bear regular interest rates. This fact should be taken into consideration when choosing the most appropriate interest rate.

Table 1. The maximum discount rates and the break-even point by site classes.

\begin{tabular}{ccc}
\hline Site class & $\begin{array}{c}\text { Discount rate } \\
(\boldsymbol{\%})\end{array}$ & $\begin{array}{c}\text { Break-even point } \\
\text { (in years) }\end{array}$ \\
\hline I & 5.66 & 45 \\
\hline II & 5.19 & 50 \\
\hline III & 4.28 & 55 \\
\hline IV & 3.74 & 55 \\
\hline V & 2.83 & 70 \\
\hline
\end{tabular}

Source: Original

It can be concluded that if wood production is selected as the main production objective, the profitability of the investment can be achieved at different discount rates depending on the site class and the length of the production cycle (Table 2).

The obtained maximum discount rates are related to the length of rotation. In most cases, an increase in the discount rate shortens the length of rotation. This means that if long rotations must be selected from the aspect of the goal that is to be attained, the profitability can be achieved only at a discount (interest) rate below the maximum value.

This points to the complexity of the problem. There are no easy solutions and each particular case requires a thorough analysis to decide on the best option which would meet both financial and economic objectives. 
In some cases (site class and rotation), the profitability of investment can be achieved at higher discount rates $(4 \%)$. This, to some extent, changes the current standing that investments in forestry can generally be profitable only at interest rates equal to or lower than 3\%. Higher interest rates can mainly be applied only to better site classes (I and II), while the interest rate for poorer site classes (III-V) ranges around the values of $3 \%$ or even less than that (Table 2).

Table 2. Break-even point of the production of wood in beech forests at different discount rates (per age).

\begin{tabular}{cccccc}
\hline $\begin{array}{c}\text { Discount rate } \\
(\boldsymbol{\%})\end{array}$ & Site class I & Site class II & Site class III & Site class IV & Site class V \\
\hline 2 & Over 140 & Over 140 & Over 140 & Over 140 & 140 \\
\hline 3 & $135-140$ & $120-125$ & 110 & $95-100$ & - \\
\hline 4 & $85-95$ & $75-80$ & $70-75$ & - & - \\
\hline 6 & - & - & - & - & - \\
\hline 8 & - & - & - & - & - \\
\hline 10 & - & - & - & - & - \\
\hline
\end{tabular}

Source: Original

It follows that the appropriate discount rate should be calculated for each particular case. The rate should correspond to the given tree species, site class and the length of the production cycle. The obtained value can be used to assess the profitability of the investments into the restitution of fire-affected beech forests.

"The duration of the production cycle" is in this case difficult to determine because the restitution of beech forests involves natural regeneration and production of wood and other forest benefits which can continue in perpetuity without any new investments. This is the fundamental difference between the forestry and standard industrial or agricultural projects, which in most cases have clearly defined duration, after which new investments are required.

\section{Intagible benefits and costs}

Apart from the dynamic method of determining the tangible benefits and costs, the static method of non-angible costs and benefits was also used. This method aims at determining the benefits that the restitution of beech forests brings to the wider community, but which cannot be expressed in monetary terms. To assess the intangible costs and benefits we used the ordinal scale of Cost-Benefit Analysis and the quantification (arithmetic operations) was done using the transformations that allow such procedures (Hastie et al., 2013). The results quantified on the basis of scoring the intensity of individual effects were used to perform the transformation (Ratknić and Braunović, 2013). The intensity of the effects and scoring are shown in Table 3.

Table 3. Assessment of intangible effects on the environment.

\begin{tabular}{ccc}
\hline Effect & Intensity & Score \\
\hline \multirow{3}{*}{ Positive or negative } & Very weak & $0-2$ \\
\cline { 2 - 3 } & Moderate & $3-5$ \\
\cline { 2 - 3 } & Significant & $6-8$ \\
\cline { 2 - 3 } & Very strong & $9-$ and over \\
\hline
\end{tabular}


The process of restitution of beech forests is in the analysis divided into two periods: a period up to 20 years of age of new stands and a period between 21 and 120 years of age, when the rotation of beech high forests is completed. We selected 33 intangible effects (benefits and costs) that make relevant factors in the restitution of beech forests destroyed by forest fires (Table 3). The data are presented collectively by type of activity in Table 4.

Table 4. Assessment of intangible benefits and costs of the planned project using the quantitative method - effects on biodiversity.

\begin{tabular}{|c|c|c|c|c|c|}
\hline 1 & 2 & 3 & 4 & 5 & 6 \\
\hline \multirow{3}{*}{$\begin{array}{l}\text { Effects by } \\
\text { type of } \\
\text { activity }\end{array}$} & \multirow{3}{*}{$\begin{array}{l}\text { Intangible benefits and costs } \\
\text { (effects) }\end{array}$} & \multicolumn{2}{|c|}{$\begin{array}{c}\text { Significance and } \\
\text { type of effect }\end{array}$} & \multicolumn{2}{|c|}{ Transformation } \\
\hline & & \multicolumn{4}{|c|}{$\begin{array}{l}\text { Scoring of the effects in the period after } \\
\text { the amelioration (in years) }\end{array}$} \\
\hline & & up to 20 & 21-120 & up to 20 & 21-120 \\
\hline \multirow{14}{*}{$\begin{array}{l}\text { Effects on } \\
\text { biodiversity } \\
\text { (including } \\
\text { species, } \\
\text { ecosystem } \\
\text { and genetic } \\
\text { diversity) }\end{array}$} & on macromycetes & -4 & +5 & 0.106 & 0.136 \\
\hline & on lichens & -4 & +5 & 0.106 & 0.136 \\
\hline & on moss & -3 & +3 & 0.076 & 0.076 \\
\hline & on the vascular flora & -10 & +10 & 0.288 & 0.288 \\
\hline & on Rotatoria & -3 & +3 & 0.076 & 0.076 \\
\hline & on the fauna of earthworms & -4 & +4 & 0.106 & 0.106 \\
\hline & on the diversity of snails & -2 & +2 & 0.045 & 0.045 \\
\hline & on the harvestman fauna & -2 & +2 & 0.045 & 0.045 \\
\hline & on the diversity of insects & -8 & +3 & 0.227 & 0.076 \\
\hline & $\begin{array}{l}\text { on the diversity of amphibians } \\
\text { and reptiles }\end{array}$ & -9 & +10 & 0.258 & 0.288 \\
\hline & on the diversity of birds & -9 & +10 & 0.258 & 0.288 \\
\hline & on mammals & -6 & +6 & 0.167 & 0.167 \\
\hline & on the ecosystem diversity & -10 & +8 & 0.288 & 0.227 \\
\hline & on the habitat fragmentation & -9 & +10 & 0.258 & 0.288 \\
\hline \multirow{10}{*}{$\begin{array}{l}\text { Effects on } \\
\text { the } \\
\text { environment }\end{array}$} & $\begin{array}{l}\text { ensuring the functioning of the } \\
\text { water regime (hydrological } \\
\text { function) }\end{array}$ & 0 & +9 & & 0.258 \\
\hline & $\begin{array}{l}\text { protection of water against } \\
\text { pollution }\end{array}$ & 0 & +8 & & 0.227 \\
\hline & $\begin{array}{l}\text { protection against harmful } \\
\text { emissions }\end{array}$ & 0 & +7 & & 0.197 \\
\hline & $\begin{array}{l}\text { regulation of soil composition } \\
\text { and fertility (and erosion } \\
\text { control) }\end{array}$ & 0 & +6 & & 0.167 \\
\hline & effect on the microclimate & 0 & +4 & & 0.106 \\
\hline & $\begin{array}{l}\text { production of oxygen and } \\
\text { purification of the atmosphere }\end{array}$ & +1 & +5 & 0.015 & 0.136 \\
\hline & $\begin{array}{l}\text { carbon binding to wood } \\
\text { volume and humic substances } \\
\text { formed under forest }\end{array}$ & +1 & +10 & 0.015 & 0.288 \\
\hline & $\begin{array}{l}\text { effect on the physical } \\
\text { appearance of the scenery } \\
\text { during exploitation }\end{array}$ & -7 & +8 & 0.197 & 0.227 \\
\hline & $\begin{array}{l}\text { rehabilitation of devastated } \\
\text { areas }\end{array}$ & 0 & +7 & & 0.197 \\
\hline & protection against noise & -3 & +4 & 0.076 & 0.106 \\
\hline
\end{tabular}




\begin{tabular}{|c|c|c|c|c|c|}
\hline 1 & 2 & 3 & 4 & 5 & 6 \\
\hline \multirow{3}{*}{$\begin{array}{l}\text { Effects on } \\
\text { the } \\
\text { community }\end{array}$} & $\begin{array}{l}\text { provision of recreational } \\
\text { opportunities }\end{array}$ & 0 & +6 & & 0.167 \\
\hline & $\begin{array}{l}\text { social benefits } \\
\text { opportunities) }\end{array}$ & 0 & +4 & & 0.106 \\
\hline & effect on human health & +1 & +8 & 0.015 & 0.227 \\
\hline \multirow{6}{*}{$\begin{array}{l}\text { Effects on } \\
\text { the economy }\end{array}$} & $\begin{array}{l}\text { provision of raw materials for } \\
\text { processing capacities }\end{array}$ & 0 & +10 & & 0.288 \\
\hline & $\begin{array}{l}\text { introduction of additional } \\
\text { economic activities }\end{array}$ & +1 & +4 & 0.015 & 0.106 \\
\hline & $\begin{array}{llr}\text { construction } & \text { of } & \text { commercial } \\
\text { properties } & \text { of } & \text { permanent } \\
\text { significance } & & \end{array}$ & -4 & +5 & 0.106 & 0.136 \\
\hline & $\begin{array}{l}\text { effect on other economic } \\
\text { activities (tourism, hunting, } \\
\text { etc.) }\end{array}$ & 0 & +8 & & 0.227 \\
\hline & $\begin{array}{l}\text { use of other forest products } \\
\text { (forest berries, medicinal } \\
\text { herbs, and mushrooms) }\end{array}$ & +1 & +8 & 0.015 & 0.227 \\
\hline & uncovered infrastructure costs & -2 & +2 & 0.045 & 0.045 \\
\hline
\end{tabular}

Source: Original

The estimate of intangible benefits and costs is based on the assumption that they will be actually achieved (although it may not always be a realistic option). The analysis of intangible benefits and costs shows that in the first 20 years after the restitution has been performed, the costs are much higher than the benefits (Table 5). The reason is that the initial phase of the restitution is carried out on the sites that have been completely destroyed by forest fires and before the normal functioning of the new ecosystem is established, the costs are higher than the benefits.

In the period from 21 to 120 years of age, when the rotation of beech high forests ends, the benefits exceed the costs, which means that restitution is justified (Table 5). Of course, it should be noted that in each case (micro-location) an analysis should be conducted to determine whether intangible costs exceed benefits.

Table 5. Quantification of the value of the estimate of intangible benefits and costs.

\begin{tabular}{lcccc}
\hline \multirow{2}{*}{ Effects by type of activity } & \multicolumn{2}{c}{ Up to 20 years of age } & \multicolumn{2}{c}{ From 21 to 120 years of age } \\
\cline { 2 - 5 } & $\begin{array}{c}\text { Cost } \\
\text { estimate }\end{array}$ & $\begin{array}{c}\text { Benefit } \\
\text { estimate }\end{array}$ & $\begin{array}{c}\text { Cost } \\
\text { estimate }\end{array}$ & $\begin{array}{c}\text { Benefit } \\
\text { estimate }\end{array}$ \\
\hline Effects on the biodiversity & 2.303 & & 2.242 \\
\hline Effects on the environment & 0.273 & 0.030 & 1.909 \\
\hline Effects on the community & & 0.015 & 0.500 \\
\hline Effects on the economy & 0.152 & 0.030 & 1.030 \\
\hline Total & 2.728 & 0.075 & 5.682 \\
\hline & & & \\
\hline Up to 20 years of age & Score (Benefit - Cost) $<0$ & $0.075-2.728=-2.653$ \\
\hline From 21 to 120 years of age & Score (Benefit - Cost) $>0$ & $5.682=5.682$ \\
\hline Total & Score (Benefit - Cost) $>0$ & $(5.682+0.075)-2.728=3.704$ \\
\hline Source: Original & &
\end{tabular}




\section{Conclusions}

Forests and their resources belong to the resources of the future because they are renewable, and with the help of science and technology, they can replace some exhausted natural resources which are certain to disappear from the Earth. The establishment of new and the improvement of existing forests would enhance other forest functions (benefits to climate, conservation, erosion control, ambient aesthetics, tourism and recreation). It would further increase the yield of other forest resources wild berries, mushrooms, medicinal and aromatic plants, or improve hunting opportunities. All in all, the cumulative effect on the level of society would be significant.

The presented results lead us to the following conclusions:

- The investment in the restitution of beech forests destroyed by forest fires can be profitable only if it is based on wood production and different discount rates can be applied depending on the site class.

- Wood production may, depending on the site class, bear slightly higher interest rates compared to previous estimates which ranged mainly around 3\%. This primarily refers to better site classes, while on poor quality sites it may fall below the limit of $3 \%$.

- The interest rate and the assessment of investment profitability are also closely related to the length of the production cycle because the break-even point varies with the discount rate. At lower discount rates, it takes more time to reach the break-even point, while the period of time needed to reach the break-even point shortens with higher discount rates. The length of production cycle plays an important role in determining the investment profitability, especially regarding the relation between the length of the production cycle and production targets (type and quality of wood assortments produced).

- Based on the analysis of intangible benefits and costs it can be concluded that the benefits outweigh the costs (generally speaking), which makes the restitution of beech forests destroyed by forest fires acceptable.

Acknowledgements. This paper was realized as a part of the project "Studying climate change and its influence on the environment: impacts, adaptation and mitigation" (No. 43007) financed by the Ministry of Education and Science of the Republic of Serbia within the framework of integrated and interdisciplinary research for the period 2011-2017.

\section{REFERENCES}

[1] Aleksić, P., Krstić, M., Jančić, G. (2009): Forest fires - ecological and economic problem in Serbia. - Botanica Serbica 33(2): 169-176.

[2] Allen, C. D., Macalady, A. K., Chenchouni, H., Bachelet, D., McDowell, N., Vennetier, M., Kitzberger, T., Rigling, A., Breshears, D. D., Hogg, E. H., Gonzalez, P., Fensham, R., Zhang, Z., Castro, J., Demidova, N., Lim, J. H., Allard, G., Running, W. S., Semerci, A., Cobb, N. (2010): A global overview of drought and heat-induced tree mortality reveals emerging climate change risks for forests. - Forest Ecology and Management 259(4): 660-684.

[3] Banković, S., Medarević, M., Pantić, D., Petrović, N. (2009): National Forest Inventory of the Republic of Serbia - Forest Fund of the Republic of Serbia, Ministry of Agriculture, Forestry and Water Management of the Republic of Serbia, Belgrade, 1-244. 
[4] Broberg, T. (2007): Examining the income-effect in contingent valuation -The importance of making the right choices. - Umeå Economic Studies 723.

[5] Brumelle, S. L., Carley, J. S., Vertinsky, I. B., Wehrung, D. A. (1991): Evaluating silvicultural investments: A review in the Canadian context, C.A.B International, Wallingford. - Forestry Abstract 9(52): 803-856.

[6] Calkin, D. E., Cohen, J. D., Finney, M. A., Thompson, M. P. (2014): How risk management can prevent future wildfire disasters in the wildland-urban interface. Proceedings of the National Academy of Sciences of the United States of America, 111(2): 746-751.

[7] Christensen, J. H., Hewitson, B., Busuioc, A., Chen, A., Gao, X., Held, I., Jones, R., Kolli, R. K., Kwon, W., Laprise, R., Ruenda, V. M., Mearns, L., Menéndez, C. G., Räisä, J., Rinke, A., Sarr, A., Whetton, P. (2007): Regional climate projections. - In: Solomon, S., Qin, D., Manning, M., Chen, Z., Merquis, M., Averyt, K. B., Tignor, M., Miller, H. L. (eds.) Climate Change: The Physical Science Basis Contribution of Working Group I to the Fourth Assessment Report of the Intergovernmental Panel on Climate Change, Cambridge University Press, Cambridge, United Kingdom/New York, NY, USA, 847940.

[8] Cicea, C., Subic, J., Cvijanovic, D. (2008): Beyond Agriculture and Rural Development: Investments, Efficiency, Econometrics. Monograph. - Institute of Agricultural Economics, Belgrade.

[9] Costanza, R., d'Arge, R., de Groot, R., Farber, S., Grasso, M., Hannon, B., Limburg, K., Naeem, S., O'Neill, R,V., Paruelo, J., Raskin, R. G., Sutton, P., Van den Belt, M. (1997): The value of the world's ecosystem services and natural capital. - Nature 387: 253-260.

[10] Ertuğrul, M., Varol, T. (2016): Evaluation of fire activity in some regions of Aegean coasts of Turkey via Canadian Forest Fire Weather Index System (CFFWIS). - Applied Ecology and Environmental Research 14(2): 93-105.

[11] Flannigan, M., Stocks, B., Turetsky, M., Wotton, M. (2009): Impacts of climate change on fire activity and fire management in the circumboreal forest. - Global Change Biology 15: 549-560. Doi: 10.1111/j.1365-2456.2008.01660.x

[12] Gonzáles-Cabán, A. (2013): The Economic Dimension of Wild Fires - Chapter 17. In: Goldammer, J. G. (ed.). Vegetation Fires and Global Change - Chellenges for Concerted International Action, A White Paper directed to the United Nations and International Organizations, A publication of the Global Free Monitoring Center (TFMC), Kessel Publishing House.

[13] Gould, J. S., Patriquin, M. N., Wang, S., McFarlane, B. L., Wotton, B. M. (2013): Economic evaluation of research to improve the Canadian forest fire danger rating system. - Forestry 86: 317-329.

[14] Greğe-Staltmane, E., Tuherm, H. (2010): Importance of Discount Rate in Latvian Forest Valuation. - Baltic Forestry 16(2): 303-311.

[15] Hansen, J., Ruedy, R., Sato, M., Lo, K. (2010): Global surface temperature change. Reviews of Geophysics 48, RG4004, doi:10.1029/2010RG000345.

[16] Hastie, T., Tibshirani, R., Friedman, J. (2013): The elements of Statistical Learning (Data Mining, Inference, and Prediction), Second Edition. - Springers Series in Statistics, 1-764.

[17] Keča, Lj., Ranković, N., Pajić, S. (2008): Analysis of commercial profitability of poplar plantations aged 24 years. - Bulletin of the Faculty of Forestry 97: 171-186.

[18] Keča, Lj., Ranković, N., Pajić, S. (2009): Analysis of commercial profitability of poplar plantations aged 29 years applying some methods of investment calculations. - Faculty of Forestry of University of Sarajevo, 1: 53-62.

[19] Lindler, M., Maroschek, M., Netherer, S., Kremer, A., Barbati, A., Garcia-Gonzalo, J., Seidl, R., Delzon, S., Corona, P., Kolström, M., Lexser, M. J., Marchetti, M. (2010): Climate change impacts, adaptive capacity, and vurnerability of European forest ecosystems. - Forest Ecology and Management 259: 698-709.

[20] Mokhtari, S., Djebabra, M., Bellaala, D., Boulagouas, W. (2017): Contribution to the 
investment evaluation in terms of the forest fires prevention using the cost-benefit analysis method. - Management of Environmental Quality 28(5): 651-663.

[21] Public Enterprise "Srbijašume" (2012): Price List of Forest Products, PE "Srbijašume", October 4th, No. 17/2012/2, (in Serbian), http://www.srbijasume.rs/pdf/cenovnik2012.pdf

[22] Pudar, Z. (1985): Economic effects of the production of poplar tree, Populus $\times$ euramericana (Dode) Guinier, cl. I-214, with two different spacing of planting, Book 13. -Poplar Research Institute, Novi Sad (in Serbian).

[23] Ratknić, M., Braunović, S. (2013): Cost-benefit analysis of establishment of Scots pine, Austrian pine and Spruce forest plantations. - Economics of Agriculture 3/2013, The Balkan Scientific Association of Agrarian Economists, Institute of Agricultural Economics, Belgrade, Academy of Economic Studies, Bucharest (Romania), 609-622.

[24] Rodriguez y Silva, F., Gonzalez Caba, A. (2010): SINAMI: A tool for the economic evaluation of forest fire management programs in Mediterranean ecosystems. International Journal of Wildland Fire 19: 927-936.

[25] Schröter, D., Zebisch, M., Grothmann, T. (2005): Climate Change in Germany Vulnerability and Adaptation of Climate-Sensitive Sectors, Klimastatusbericht 44, www.umweltbundesamt.org/fpdf-I/2978.pdf

[26] Sekulić, G., Dimović, D., Kalmar, Z., Krnajski, J., Todorović, N. (2012): Assessing vulnerability to climate change - Serbian, WWF (World Wide Fund for Nature). - Center for the Advancement of Environment, Belgrade.

[27] Subić, J. (2010): Specificity of the process of investing in agriculture. - Institute of Agricultural Economics, Belgrade (in Serbian). 